\title{
CHIMERISM INDUCTION BY NONMYELOABLACTIVE PRECONDITIONING AND BONE MARROW INFUSION IN RAT SMALL BOWEL TRANSPLANTATION ${ }^{1}$
}

\author{
Alexandre Bakonyi Neto ${ }^{2}$ \\ Mariana Behro ${ }^{3}$ \\ Phillip Ruiz ${ }^{3}$ \\ Evangelos P. Misiakos ${ }^{4}$ \\ Joshua Miller $^{5}$ \\ Bonifacio K. Takegawa ${ }^{7}$ \\ Camilo Ricordi ${ }^{6}$ \\ Andreas G. Tzakis ${ }^{4}$
}

\begin{abstract}
Bakonyi Neto A, Behro M, Ruiz P, Misiakos EP, Miller J, Takegawa BK, Ricordi C, Tzakis AG. Chimerism induction by nonmyeloablactive preconditioning and bone marrow infusion in rat small bowel transplantation. Acta Cir Bras [serial online] $2003 \mathrm{Jan}-\mathrm{Feb}$;18(1). Available from URL: http://www.scielo.br/acb.
\end{abstract}

\begin{abstract}
In our previous work we demonstrated that the use of donor specific bone marrow infusions ( DSBMI ) after small bowel transplantation did not improve the graft survival after a short course of immunossupression. Purpose: In the current study, we evaluated whether recipient preconditioning with different regimens of radiation combined with DSBMI may enhance small bowel allograft survival with minimum recipient morbidity. Methods: Heterotopic small bowel transplantation (SBTx) was performed with Lewis rats as recipients and DA rats as donors, which were immunossupressed with a short course of tacrolimus (FK 506 ) at $1 \mathrm{mg} / \mathrm{Kg} /$ day for 5 days and distributed in 4 groups: group $1(n=4)$ without both irradiation and DSBMI; Groups $2(n=6)$, $3(n=9)$ and $4(n=6)$ received $100 \times 10^{6}$ DSBM cells at the time of the transplant. Groups 3 and 4 were irradiated with 250 and 400 rd respectively. Animals were examined daily for clinical signs of rejection or GVHD. Blood samples were taken weekly for chimeric studies by FC and intestinal biopsies were performed every 2 weeks. Results: Animals in G1 and G2 had minimal rejection at day 15 after SBTx while GVHD was clinically and histologically characterized in G 3 and G 4. Total chimerism and T-cell chimerism was higher in irradiated groups when compared to non-irradiated groups. With exception of G1 and 2 where rejection was the cause of death, all animals in G3 and 4 died of GVHD. Conclusion:We concluded that low cytoreductive of irradiation can successfully decrease the graft rejection but not prevent the occurrence of GVHD.
\end{abstract}

KEY WORDS - Intestinal transplant. Bone marrow infusion. Irradiation.

1. University of Miami School of Medicine, Division of Liver and GI Transplantation

2. Assistant Professor, PhD - Department of Surgery from Botucatu Faculty of Medicine (UNESP); Ex-fellow of Transplant Division at the University of Miami.

3. Department of Pathology/ Division of Immunopathology, Transplant Division at the University of Miami.

4. Transplant Division at the University of Miami.

5. Department of Surgery/ Division of Kidney and Pâncreas Transplantation, Transplant Division at the University of Miami.

6. Diabetes Research Institute and Cell Transplantation Center, Transplant Division at the University of Miami.

7. Assistant Professor-Department of Surgery from Botucatu Faculty of Medicine. 


\section{INTRODUCTION}

Despite the improvements in post-transplant immunosupressive regimens, the control of allograft rejection is still dependent on the use of nonspecific immunosupressive agents, which is frequently associate to complications, such as infections and lymphoproliferative disorders (1).

The successfully induction of specific tolerance continues to be a challenger in recipients after a solid organ transplantation. Methods to enhance the natural microchimerism are currently explored using donor specific bone marrow (BM) cells, in order to facilitate the development of donor-specific tolerance after transplant. In a previous work (2) we compared the effect of single or multiple donor specific bone marrow infusions (DSBMI) after small bowel transplantation. An increased susceptibility to severe rejection and increased mortality were observed in groups treated with DSBMI when started early after transplant and immunosupressed with a short course of tacrolimus . Severe rejection were also observed in recipients after delayed infusions that were given upon discontinuation of immunosupression, suggesting that immunosuppressive and/or immunomodulatory strategies may be needed for longer periods of time when BM are used.

The inability to achieve a stable chimeric state did not allow us to determine the effect of chimerism on graft and recipient survival after small bowel transplantation. Based on this background, we are trying to find the irradiation doses in rats that allows the engraftment of a small bowel allograft and bone marrow cells in order to achieve tolerance after transplant without rejection and graft versus host disease. In this study we compare whether nonmyeloablactive preconditioning given by low and high doses of irradiation associated with unmodified donor bone marrow infusions and short course of immunosuppression can enhance small bowel allograft and recipient survival.

\section{METHODS}

Animals: Small bowel transplantation was performed using a fully histoincompatible rat strain combination. Male DA (Rt1 ${ }^{\text {a }}$ ) weighing 80 to $100 \mathrm{~g}$ were used as donors and female Lewis $\left(\mathrm{Rt}^{1}{ }^{1}\right)$ weighing $180 \mathrm{~g}$ as recipients. The animals were obtained from Harlan Sprague Dawley (Indianapolis, IN) and housed at the Division of Veterinarian Resources of the University of Miami.

Small bowel transplantation: Heterotopic small bowel transplant was performed using standard microvascular techniques (3). Under metofane anesthesia, the abdomen was opened by a midline incision. The donor small bowel (jejunum-ileum) was removed after intraluminal and intravascular irrigation with cold heparinized saline solution $\left(4^{\circ} \mathrm{C}\right)$. The bowel was excised with its intact vascular pedicle consisting of the superior mesenteric artery with an aortic cuff and the portal vein. The graft was kept at $4^{\circ} \mathrm{C}$ until transplantation.

The recipient abdomen was opened and the graft was reperfused by anastomosing the aortic cuff to the recipient infrarenal aorta, while the portal vein was anastomosed to the recipient inferior vena cava. The proximal and distal ends of the graft were exteriorized as stomas (Thiry-Vella Loop).

Animals surviving less than 48 hours were considered technical failures and excluded. All animals were fed with a regular laboratory diet and water beginning immediately after transplant.

Experimental design: Twenty-three male DArats and twenty-three female Lewis rats were used as donors and recipients, respectively, for a heterotopic small bowel transplant. Animals were distributed into 4 groups: group $1(\mathrm{n}=4)$, without both irradiation and DSBMI; group $2(n=6)$, group 3 (9) and $4(n=4)$ received $100 \times 10^{6} \mathrm{BM}$ cells. Recipients in groups 3 and 4 was given 250 and 400 rd of total body irradiation (TBI) from a cesium-137 source 1 to 2 hours prior the small bowel transplant. The animals in groups $1,2,3$ and 4 were immunosupressed with $1 \mathrm{mg} / \mathrm{kg} / \mathrm{FK} \mathrm{506/}$ IM/ for 5 days, started at the day of the transplant.

Bone Marrow Preparation: Fresh donor bone marrow was obtained from femurs and tibias of exsanguinated donor rats after removal of the small bowel. Bone marrow was harvested from the long bones by flushing with RPMI 1640 medium (Life Technologies, Grand Island, NY), using a 23-gauge needle. The bone marrow cells were gently resuspended using an 18-gauge needle and filtered through sterile nylon mesh. The viability of the cells was checked by trypan blue exclusion and counted before infusion. Trypan blue exclusion test always showed $>95 \%$ viability before infusion. The bone marrow cells were then pelleted by centrifugation at $1500 \mathrm{rpm}$ for $10 \mathrm{~min}$, ressuspended and cell concentration adjusted so that the total number of cells $\left(80-100 \times 10^{6}\right)$ was injected in a $1 \mathrm{ml}$ volume in the femoral vein after dissection immediately after transplant.

Postoperative follow-up: Rats were observed daily for clinical signs of graft-versus-host disease (GVHD), such as diffuse erythema (particularly of the ears and extremities), hyperkeratosis of the footpads, skin rash, anorexia, diarrhea and unkempt appearance. The abdomen was palpated daily to detect development of a palpable abdominal mass, a characteristic signal of graft rejection. 
Postoperative assessment of chimerism by flow cytometric analysis: Blood samples were collected weekly by tail puncture into anti-coagulated (EDTA) plastic serum vials after light anesthesia. Flow cytometry detection of cells expressing DA rats class I antigen (haplotype RT $1^{\text {a }}$ ), were done with a two color staining protocol for whole blood. Briefly, $100 \mathrm{ml}$ of a two color cocktail (FITC-conjugated Mab to RT $1^{\mathrm{a}}$ and $\mathrm{PE}$-conjugated anti-rat $\mathrm{CD} 3$, both from PharMingen, San Diego, CA) were incubated with $100 \mathrm{ml}$ of whole blood. After an incubation of 30 minutes, the red blood cells $(\mathrm{RBC}$ ) were lysed (with lysing reagent for whole blood Becton/Dickinson San Jose, CA). The presence of donor cells in the recipient Lewis rat (DA cells circulating in the Lewis blood stream) were classified as $T$ cells and non-T cells.

The complete analysis was obtained by gating on mononuclear cells by size and granularity first, then segregating the RT $1^{\mathrm{a}}$ positive cells over a background of a non transplanted Lewis (negative control) and within the spectrum of a normal DA (positive control). An additional segregation was done on this last to determined which where also expressing CD3 epitopes. All the analysis were done in a Facs Calibur flow cytometer, San Jose (CA).

Post-transplant biopsies and pathologic studies: Biopsies from the ileostomy and skin were taken every fifteen and thirty days respectively after transplant to assess the presence of rejection and GVHD. Tissue samples were fixed in $10 \%$ buffered formalin, embedded in paraffin, sectioned at $4 \mathrm{~mm}$ and stained with hematoxylin and eosin. For each biopsy a combination of histological parameters were applied to assess acute and chronic rejection. Acute rejection was graded as mild, moderate and severe based on a semiquantitative scoring system.

The graded features included surface and crypt epithelial injury (reactive epithelial atypia, cryptitis, apoptotic bodies and presence of crypt abscesses), villous blunting, mucosal ulceration, and vasculitis. A diagnosis of chronic rejection was rendered when prominent obliterative vasculopathy was noted.
Statistics: The significance of differences between means was determined by using the Anova and two-tailed Student's t-test for paired samples. Values were considered statistically significant for $\mathrm{p}<0.05$.

\section{RESULTS}

Histopathologic studies: Ileal biopsies obtained on day 15 after transplant showed minimal to mild acute rejection in groups 1,2 and 3, while no rejection was observed in group 4 (high radiation regimen). With exception of group 1 and 2, that showed severe acute and early chronic rejection at day 30 , the same histologic pattern of minimal to mild acute rejection was observed in the remaining groups during the experiment. GVHD was clinically and histologically characterized as moderate to severe only in groups submitted to irradiation (groups 3 and 4).

Survival: Clinical evidence of GVHD after transplant, such as diffuse erythema (particularly on the ears and extremities), hyperkeratosis of the footpads, skin infections, anorexia, diarrhea, unkempt appearance and weight loss were the common pattern in groups 3 and 4 , started 3 weeks after transplant. Median survival time was 60,54, 36 and 43 days in groups 1,2,3, and 4 respectively. With exception of group 1 and 2 where rejection was the cause of death, all animals in groups 3 and 4 died of GVHD.

Chimeric studies: Figure 1 and Table 1 shows the total chimerism levels (CD3+ and

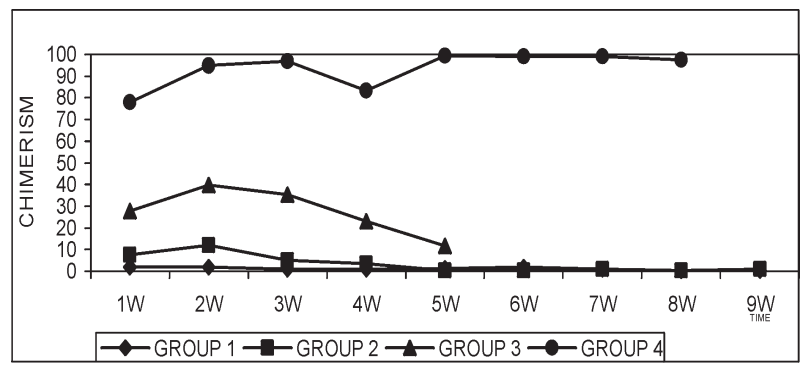

Group 1 and $2<$ Group 3 and $4(\mathrm{p}<0.05)$

FIGURE 1 - Total chimerism between groups.

TABLE 1 - Average of Total Chimerism (CD3+ and others cells) and T-cell Chimerism (CD3+ cells) between groups.

\begin{tabular}{lc|c|c|c}
\hline \multicolumn{2}{c|}{ Experimental groups } & \% Total Chimerism & \% T-cell Chimerism & Median Survival (days) \\
\hline SITx & $(\mathrm{n}=4)$ & 0.2 to $1.9 \%$ & 0.0 to $0.88 \%$ & 60 \\
\hline SITx + BM & $(\mathrm{n}=6)$ & 0.2 to $12 \%$ & 0.0 to $2.89 \%$ & 54 \\
\hline SITx+BM+250rd $\quad(n=9)$ & 11.7 to $39.8 \%$ & 0.5 to $20.6 \%$ & 36 \\
\hline SITx + BM+400rd $\quad(n=4)$ & 77.9 to $99.2 \%$ & 12.0 to $63.8 \%$ & 43 \\
\hline
\end{tabular}

SITx: small intestinal transplantation

rd: irradiation 
others cells) in all groups. The median chimerism in group 1 (control) and 2 varied from $0 \%$ to $1,93 \%$ and $0,2 \%$ to $12 \%$ of donor cells respectively. In groups 3 and 4 (irradiation groups) the chimerism levels varied from $11,78 \%$ to $39,84 \%$ and $77,9 \%$ to $99,28 \%$ respectively. The high levels of chimerism were observed in irradiated groups and the differences were statistically significant.

The analysis of donor T-cells (CD3+) in recipients showed a statistically significant higher chimerism in irradiated groups ( median of $15 \%$ in group 3 and $50 \%$ in group 4) while $0,5 \%$ and $2 \%$ in groups 1 and 2 respectively ( Table 1 and Figure 2 ).

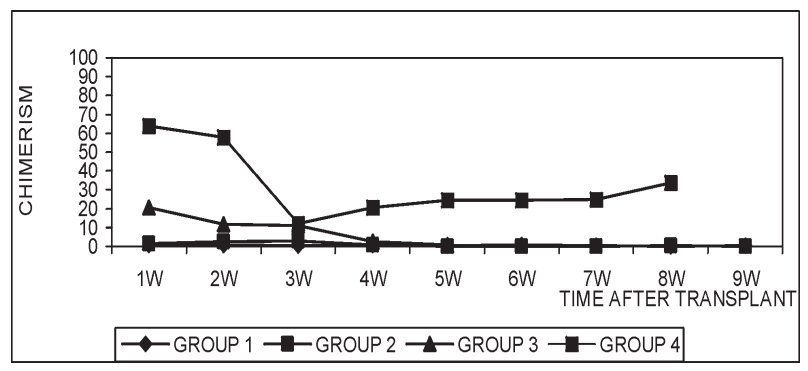

Group 1 and $2<$ Group 3 and $4(p<0.05)$

FIGURE 2 - CD3 + cells in peripheral blood between groups.

The differences in chimerism levels between groups were observed mainly in the first week after transplant.

\section{DISCUSSION}

The use of high dose of irradiation (lethal and sublethal) leads to a severe alterations in hematopoietic rat system, with the occurrence of graft versus host disease and death of the animals when bone marrow infusions are used.

The nonmyeloablactive conditioning strategies based in low dose of total body irradiation as used in this study and by others (4) can decrease the morbidity and mortality associated with the conditioning regimens and produce a mixed multilineage chimerism.

The conditioning regimen, besides to creates space or microenvironment for the donor bone marrow to engraft, also has immunosupressive effects (5). The utilization of bone marrow infusions togheter with an organ in several clinical protocols improved the results after kidney and liver transplantation, as evidenced by graft survival, number of rejection episodes and chimerism augmentation.
Although the mechanism of tolerance induction by bone marrow infusion is not clearly understood, it has been postulated that the interaction of two coexisting donor and recipient leukocyte population led to the downregulation of immune response to donor antigen by recipient cells and likewise hyporesponsiveness to recipient by donor immunocompetent leukocytes.

High levels of donor cells were observed in recipients in this study, and were proportional to the irradiation regimen used when compared to nonirradiated groups. A multilineage mixed chimerism was observed in low dose irradiation group while a total allogeneic chimerism was observed in high dose irradiation group.

The appearance of rejection in group 4 only after 30 days and the decreased severity of rejection in group 3 when compared to groups 1 and 2 means that irradiation regimens based on 250 rd or more has immunosuppressive effects, by eradicating or inactivating the cells involved in rejection (5) .

However, an increased morbidity and mortality related to graft-versus-host disease (GVHD) were associated to the irradiation regimens used. Probably the high levels of donor CD3+ cells in peripheral blood in irradiated recipients, migrated from the intestinal allograft or from bone marrow source might play a role in GVHD occurrence.

A stable chimerism could not be achieved with a short course of immunossupression without recipient preconditioning and further studies are necessary to evaluate whether prolonged immunossupression and T-cell depletion of DSBM can avoid the appearance of GVHD in this model.

\section{CONCLUSION}

Low cytoreductive regimen of irradiation can successfully decrease the severity of graft rejection but not prevent the occurrence of GVHD after transplant.

\section{REFERENCES}

1. Misiakos EP, Weppler D, Bakonyi Neto A, Pinna AD, Nery JR, Khan FA, Thompson J, Viciana A, Tzakis AG . The current status of small bowel transplantation: the experience at the University of Miami. Arch Gastroenterohepatol 1998; 17:37-44.

2. Bakonyi Neto A, Ricordi C, Feo C, Porcu A, Misiakos E, Gandia C, Ruiz P, Behro M, Carreno M, Esquenazi V, Miller J, Tzakis AG. Correlation between allograft survival and quimeric state after bone marrow infusion in rat small bowel transplantation. Pediatr Transplant 1999; 3:1-7.

3. Monchic GJ, Russel PS. Transplantation of small bowel in the rat: technical and immunological considerations. Surgery 1971; $70: 693-7$

4. Gammie JS, Li S, Colson YL, Demetris AJ, Neip M, Ildstad ST, Phan SM. A partial conditioning strategy for achieving mixed quimerism in the rat: tacrolimus and anti-lymphocyte serum 
substantially reduce the minimum radiation dose for engraftment. Exp Hematol 1998; 26:927-37.
5. Martin PJ. Determinants of engraftment after allogeneic marrow transplantation. Blood 1992; 9:1647-53.

Bakonyi Neto A, Behro M, Ruiz P, Misiakos EP, Miller J, Takegawa, BK, Ricordi C, Tzakis AG. Indução de quimerismo com a utilização de precondicionamento não mieloablativo e infusão de medula óssea nos transplantes de intestino delgado em ratos. Acta Cir Bras [serial online] 2003 JanFev;18(1). Disponível em URL: http://www.scielo.br/acb.

RESUMO - Em estudo recente demonstramos que a infusão de células da medula óssea do doador após o transplante intestinal não aumentou a sobrevida do enxerto quando se utilizou series curtas de drogas imunossupressoras. Objetivo: Neste estudo avaliamos se a utilização de diferentes regimes de irradiação em associação com a infusão de medula óssea altera a sobrevida do enxerto e a morbidade sobre receptor. Métodos: Realizou-se o transplante heterotópico de intestino delgado, utilizando-se ratos Lewis como receptores e DA como doadores, imunossuprimidos com FK 506 na dose de $1 \mathrm{mg} / \mathrm{kg} /$ dia por 5 dias e distribuídos em 4 grupos: $\mathrm{Gl}(\mathrm{n}=4)$, não irradiado e sem infusão de medula óssea; G2 (n=6), G3 $(n=9)$ e G4 $(n=6)$ foram infundidos com 100 x $10^{6}$ células de medula após o transplante. Grupos 3 e 4 foram irradiados com 250 e 400 rd respectivamente. Os animais foram examinados diariamente para a detecção de rejeição e reação do enxerto versus hospedeiro, tendo sido colhidas amostras semanais de sangue para estudos de quimerismose biopsias quinzenais da estomia. Resultados: Animais nos G1 e G2 apresentaram rejeição mínima no $15^{\circ}$ pós-operatório, enquanto a reação do enxerto versus hospedeiro foi caracterizada nos G3 e G4. Os níveis de quimerismo total e de células $\mathrm{T}$ foram maiores nos grupos irradiados em comparação aos não irradiados. A causa mortis nos G1 e G2 foi a rejeição enquanto que nos $\mathrm{G} 3$ e G4 foi a reação do enxerto versus hospedeiro. Conclusão: Concluímos que a utilização de baixas doses de irradiações retardam o aparecimento da rejeição, mas não previne a ocorrência da reação do enxerto versus hospedeiro.

DESCRITORES - Transplante intestinal. Infusão de medula óssea. Irradiação.

Conflict of interest: none Financial source: $\mathrm{CNPq}$

Address for correspondence:

Alexandre Bakonyi Neto

Rua Hortência, 66

18603-660 Botucatu - SP

fefofofo@1aser.com.br

Data do recebimento: $12 / 09 / 2002$

Data da revisão: 28/09/2002

Data da aprovação: 10/10/2002 